University of Rhode Island

DigitalCommons@URI

$11-8-2017$

\title{
ResearchGate vs. the Institutional Repository: Competition or Complement?
}

Julia Lovett

University of Rhode Island, jalovett@uri.edu

Andrée Rathemacher

University of Rhode Island, andree@uri.edu

Follow this and additional works at: https://digitalcommons.uri.edu/lib_ts_presentations

Part of the Scholarly Communication Commons, and the Scholarly Publishing Commons

Creative Commons License

(c) (i)

This work is licensed under a Creative Commons Attribution 4.0 License.

\section{Recommended Citation}

Lovett, Julia and Rathemacher, Andrée, "ResearchGate vs. the Institutional Repository: Competition or Complement?" (2017). Technical Services Faculty Presentations. Paper 54.

https://digitalcommons.uri.edu/lib_ts_presentations/54

This Article is brought to you for free and open access by the Technical Services at DigitalCommons@URI. It has been accepted for inclusion in Technical Services Faculty Presentations by an authorized administrator of DigitalCommons@URI.For more information, please contact digitalcommons-group@uri.edu. 
Summary: The popularity of academic social networks like ResearchGate and Academia.edu indicates that scholars want to share their work, yet for universities with Oper Access $(\mathrm{OA})$ policies, these sites may be competing with institutional repositories for content. Our study seeks to reveal researcher practices, attitudes, and motivations around uploading their work to ResearchGate and complying with an institutional Open Access Policy. We conducted a population study to examine the participation by 558 full-time University of Rhode Island faculty members in the OA Policy and ResearchGate, followed by a survey of 728 full-time URI faculty members about their participation in the two services.

Finding 1: While a slightly greater percentage of faculty have shared articles through ResearchGate than through the OA Policy, only a minority of faculty $(29 \%)$ are participating in either ResearchGate, the OA Policy, or both. Contrary to expectations, faculty who participate in ResearchGate are actually more likely to share their articles via the Open Access Policy than faculty who do not participate in ResearchGate, and vice versa. This suggests librarians should not be overly concerned about academic social networking sites competing with OA policies; if anything, faculty who participate in academic social networking sites may be more likely to share their work in general.

Finding 2: Faculty reported a strong aversion to sharing the author manuscript version of their articles. This was the most significant barrier to participating in the $O A$ Policy. This finding, if generalizable, should inform current discussions among OA advocates about the respective roles going forward of Green OA achieved through depositing author manuscripts in institutional repositories and Gold OA achieved at the point of publication.

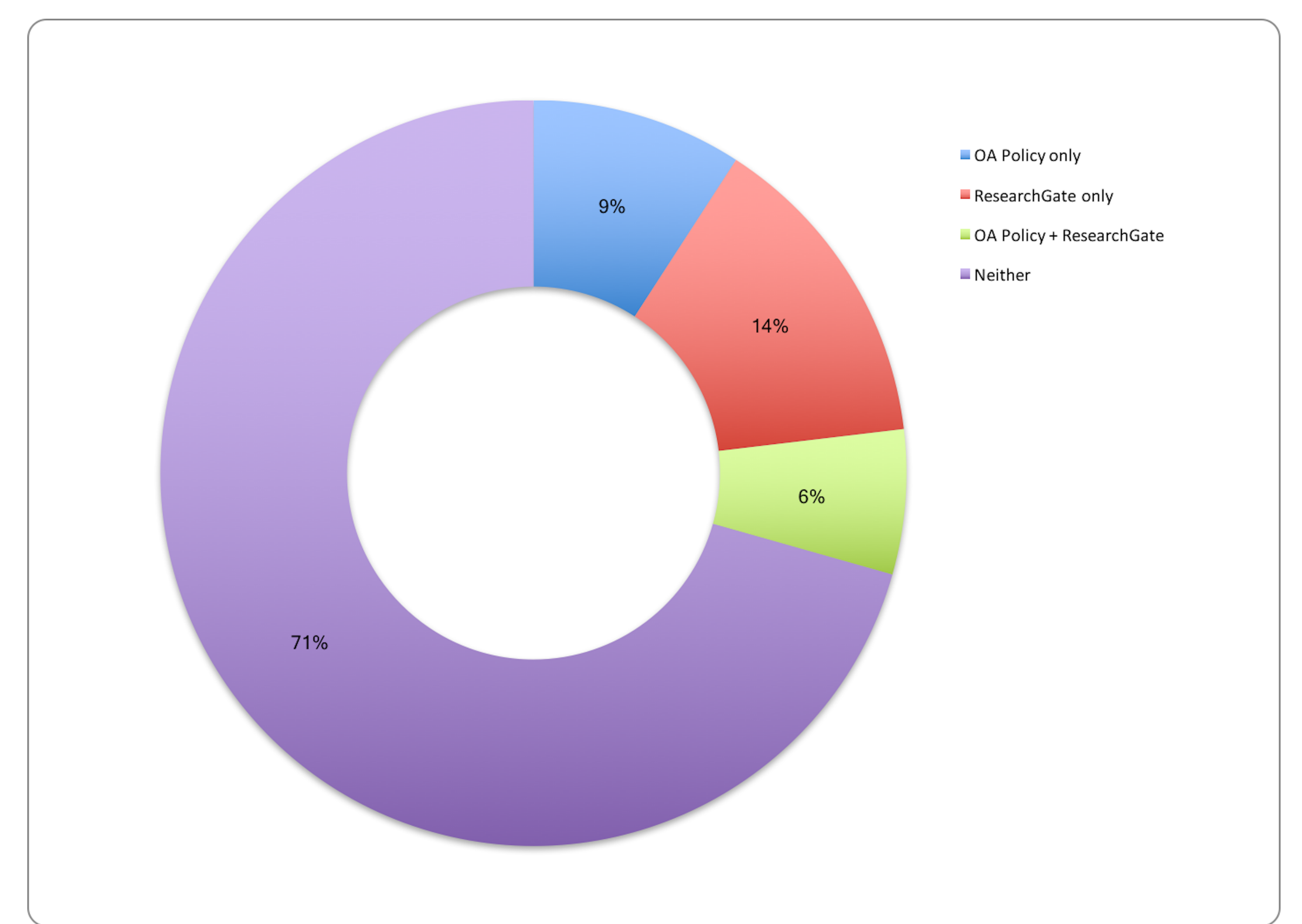

1. Faculty participation in URI Open Access Policy and ResearchGate $(n=558)$

\begin{tabular}{|c|c|c|}
\hline & $\begin{array}{r}\text { Open Access } \\
\text { Policy }\end{array}$ & ResearchGate \\
\hline Participation is too time consuming & $23.5 \%$ & $7.3 \%$ \\
\hline $\begin{array}{l}\text { I'm concerned that publishers might retaliate and not } \\
\text { publish my article or my future articles }\end{array}$ & $10.3 \%$ & $7.3 \%$ \\
\hline $\begin{array}{r}\text { I'm concerned about the effects of Open Access on } \\
\text { publishers }\end{array}$ & $11.8 \%$ & $12.7 \%$ \\
\hline $\begin{array}{l}\text { I don't like having my manuscript version available } \\
\text { instead of the final published PDF }\end{array}$ & $42.7 \%$ & $\mathrm{n} / \mathrm{a}$ \\
\hline $\begin{array}{r}\text { I'm concerned my work will be plagiarized or } \\
\text { misused }\end{array}$ & $8.8 \%$ & $9.1 \%$ \\
\hline $\begin{array}{r}\text { Participation is more difficult when I'm not the lead } \\
\text { author }\end{array}$ & $16.2 \%$ & $14.6 \%$ \\
\hline I'm concerned about the legality of participating & $8.8 \%$ & $30.9 \%$ \\
\hline Other (please specify) & $32.4 \%$ & $41.8 \%$ \\
\hline
\end{tabular}

2. Concerns about participating in the OA Policy $(n=68)$ and having articles available in ResearchGate $(n=55)$

\begin{tabular}{|r|r|r|}
\hline & $\begin{array}{r}\text { Open Access } \\
\text { Policy }\end{array}$ & ResearchGate \\
\hline Legal under copyright law & $50.4 \%$ & $21.4 \%$ \\
\hline Violates the copyright of the publisher & $8.4 \%$ & $17.5 \%$ \\
\hline Not sure & $41.2 \%$ & $61.1 \%$ \\
\hline
\end{tabular}

3. Opinion of legality of complying with the OA Policy $(n=131)$ and posting article full-texts on ResearchGate $(n=126)$
Finding 3: Our survey revealed a range of misunderstandings about the institutional repository (IR), OA policies, and copyright. For example, many respondents believe that the legality of posting one's articles in both the IR and ResearchGate depends on publisher policy and the version of the article posted. In fact, permissions-based OA policies make it legal to post author manuscripts in the IR regardless of publisher policies, and many subscription-access journals prohibit depositing any version of an article to commercial sites like ResearchGate. These misunderstandings indicate a need for librarians to conduct greater education and outreach to faculty around their options for legally sharing published articles.

Conclusion: Librarians should not view academic social networks as a threat to Open Access. Authors' strong preference for sharing the final, published version of their articles provides support for calls to hasten the transition to a Gold OA publishing system. Misunderstandings about the OA Policy and copyright indicate a need for librarians to conduct greater education and outreach to authors about options for legally sharing articles.

\section{Contact:}

Julia Lovett

Assistant Professor, Digital Initiatives Librarian jalovett@uri.edu

Andrée Rathemacher

Professor, Head of Acquisitions andree@uri.edu 